\title{
Effect of 5-HT3 serotonergic receptor blockade on the evaluation of thermal, mechanical pain thresholds and conditioned pain modulation in humans.
}

\author{
Bruno Vítor Santiago ${ }^{1}$, Bruno Parada ${ }^{2}$, Maud Parise $^{2}$, and Nivaldo Villela ${ }^{2}$ \\ ${ }^{1}$ State University of Rio de Janeiro Biomedical Centre \\ ${ }^{2}$ Rio de Janeiro State University
}

August 25, 2020

\begin{abstract}
One form known as pain modulation is the phenomenon of inhibiting pain using a prior pain stimulus. The term CPM (conditioned pain modulation) is used to describe this phenomenon in humans. Serotonin pathways work as both anti- and pro-nociceptive pathways. Ondansetron is a 5HT3 receptor antagonist routinely used to prevent postoperative nausea and vomiting. Therefore, this study's objective was to evaluate ondansetron's effect on mechanical and thermal pain thresholds, as well as CPM in humans. 17 volunteers, who were randomly selected and double-blinded, participated in the research. They received an intravenous solution containing $1-\mathrm{NaCl}$ at $0.9 \%$, in a volume of $20 \mathrm{~mL} ; 2-\mathrm{NaCl}$ at $0.9 \%$ and $8 \mathrm{mg}$ ondansetron in a volume of $20 \mathrm{~mL}$. Using the quantitative sensory test (QST), we obtained the thresholds for detecting warm and cold; pain thresholds to hot and cold; the pressure pain threshold. CPM was evaluated using the parallel paradigm in which two identical nociceptive test stimuli were induced before and simultaneous to a conditioned nociceptive stimulus. Thirty minutes after the intervention, we redid the tests. We repeated the tests one week later but using the different solution so that each participant was their own control (crossover). We used the Wilcoxon test to compare the variables. Ondansetron, intravenously, improved CPM $(\mathrm{p}<0.05)$ and influenced thermal detection thresholds (heat and cold $\mathrm{p}<0.05)$. There is evidence that the results related to the antagonism of the $5 \mathrm{HT}-3$ receptor by ondansetron, occur through inhibition of facilitating descending pathways, improving the CPM.
\end{abstract}

\section{Hosted file}

Article for BJP _ Bruno_ Santiago_final_version.doc available at https://authorea.com/users/ 353641/articles/477437-effect-of-5-ht3-serotonergic-receptor-blockade-on-the-evaluationof-thermal-mechanical-pain-thresholds-and-conditioned-pain-modulation-in-humans

\section{Hosted file}

Table 1..docx available at https://authorea.com/users/353641/articles/477437-effect-of5-ht3-serotonergic-receptor-blockade-on-the-evaluation-of-thermal-mechanical-painthresholds-and-conditioned-pain-modulation-in-humans 


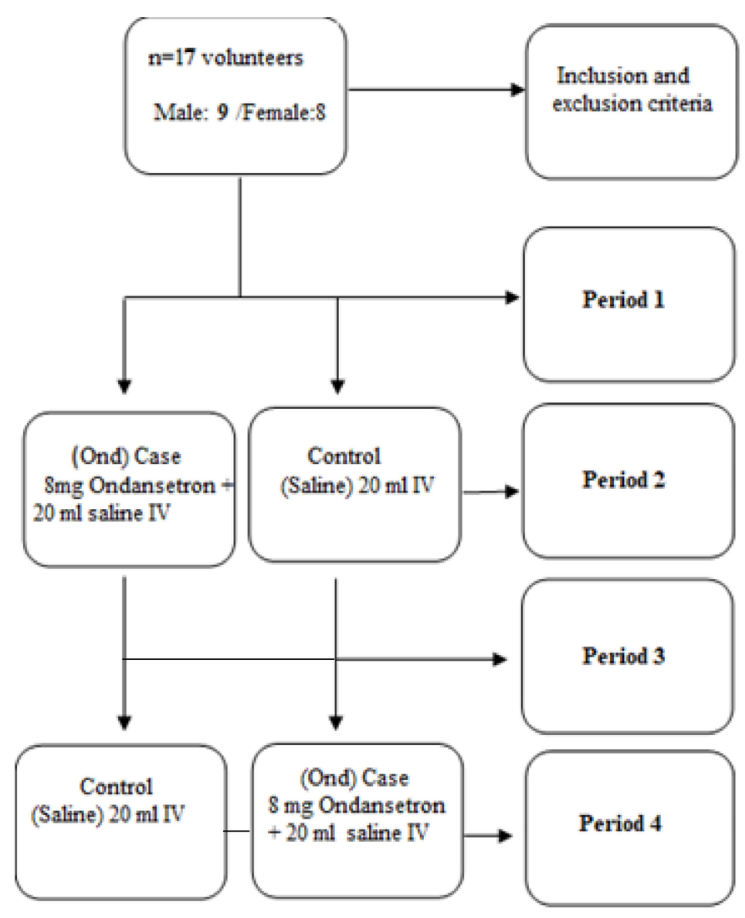

A Cold Detection Treshold (CDT)
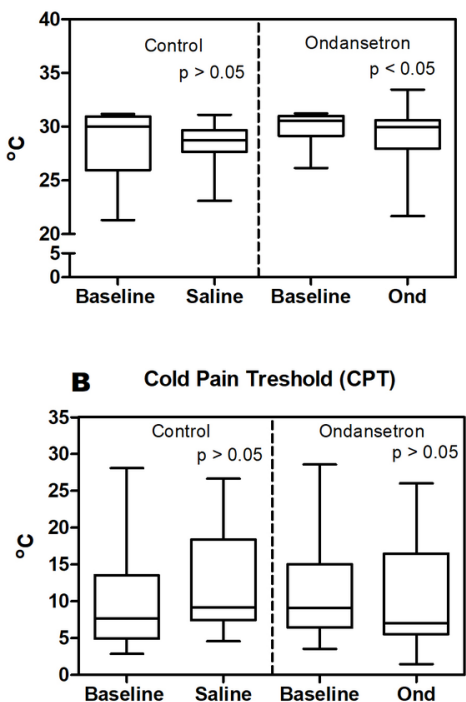

C Warm Detection Treshold (WDT)
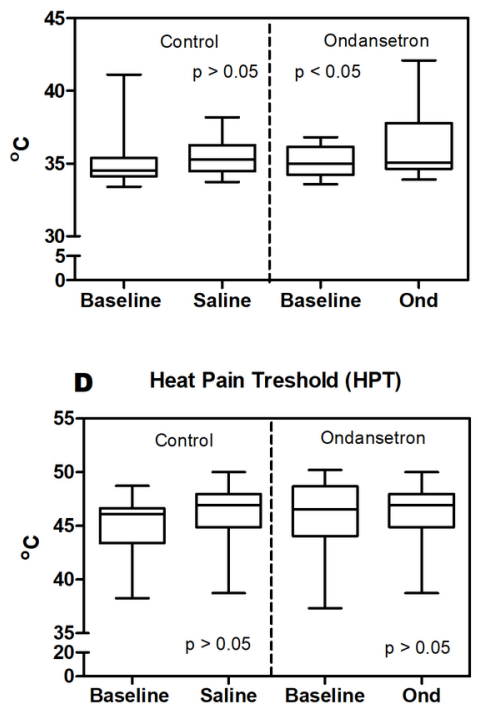

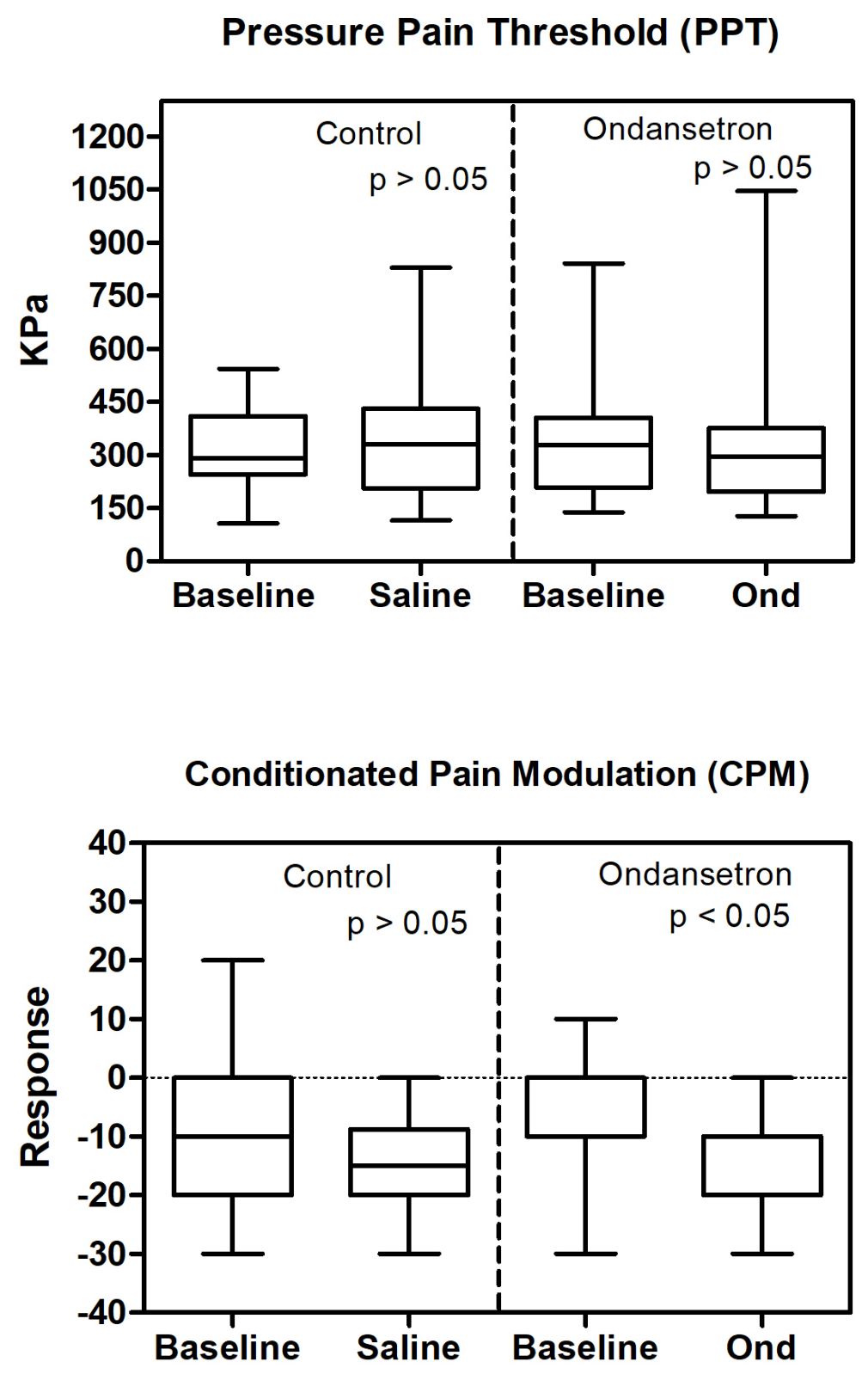